Original article

\title{
The Effectiveness of Cognitive-Behavioral Therapy on Emotional Control of MS Patients in the City of Isfahan
}

\author{
Maedeh Sadat Alavi ${ }^{1}$, Sheida Jabalameli ${ }^{1 *}$
}

1. Department of Psychology, Najafabad Branch, Islamic Azad University, Najafabad, Iran (00000002-1288-9180), (0000-0001-9948-7231)

\begin{abstract}
Background and objectives: Cognitive-behavioral therapy is one of the interventions used in the treatment of chronic medical conditions such as MS in recent years. Hence, this study was designed to determine the effectiveness of cognitive-behavioral therapy on emotional control of MS patients in the city of Isfahan.
\end{abstract}

Methods: The present study was a semi-experimental research which was conducted by using a pretest-posttest design with the control group. The study population consisted of all members of the MS Society of Isfahan in 2016-2017. Using the available sampling method, 30 subjects were selected and randomly divided into two experimental and control groups (15 subjects for each group). Both groups completed Williams and Chambless emotional control questionnaire as the pretest. After eight sessions (two one-hour sessions per week for four weeks) of cognitive-behavioral therapy, the posttest was performed for the groups. The data were analyzed using descriptive statistical methods, including mean and standard deviation and inferential statistics including univariate covariance analysis in the SPSS 20 software.

Results: The study participants included 16 married women and 14 married men. The mean age of the participants in the experimental and control groups was $30.23 \pm 7.06$ and $29.34 \pm 7.15$, respectively. The results of the univariate covariance analysis showed that a significant difference in the mean scores of emotional control from the pre-test to the post-test stage between the experimental group and the control group $(P=0.001)$. Thus, in the experimental group, the mean total score of emotional control in the pretest and post-test phases was equal to 71.66 and 31.33, respectively, while these values in the control group in the pre-test and post-test phases were 67.06 and 62.93, respectively. Also in the experimental group, the scores of four sub-scales of anger, depressed mood, anxiety, and positive emotions revealed significant differences between the posttest stage and the pre-test stage $(P=0.001)$. Therefore, the cognitive-behavioral therapy was effective in improving the emotional control of MS patients.

Conclusion: Considering the effectiveness of cognitive-behavioral therapy, we recommended the use of this therapeutic method to improve the emotional control of the patients with MS.

Keywords: Cognitive-Behavioral Therapy, Emotional Control, MS

Corresponding Author: Sheida Jabalameli

Address: Department of Psychology, Najafabad Branch, Islamic Azad University, Najafabad, Iran

E-mail: sh.jabalameli@yahoo.com 


\section{Introduction}

Multiple Sclerosis (MS) is one of the most common diseases of the central nervous system in young people. By damaging the myelin tissue of the brain and the spinal cord, this chronic and progressive disease causes a wide range of neurological symptoms such as blurred vision, muscle weakness and sensory impairments (1). The neurological symptoms initially include weakness, ataxia, diffuse sensory and motor disturbances and visual changes (2). About 40,000 people in Iran suffer from this disease according to a report by the Iranian MS Association (3). The most common age to develop this disease ranges from 20 to 40 years old (4) and the prevalence of the disease has been more pronounced among women (5).

MS appears also to be a chronic and progressive disease with significant economic and social consequences. The social costs associated with MS are so high due to the long duration of the illness, the early loss of efficiency, the need for assistance in daily activities, immunomodulatory therapies and multiple modalities health care measures (6). The disease affects the young people and threatens the individual's independence and ability to effectively participate in the family and community and leads him to lose the sense of competence and self-confidence (7). The MS diagnosis challenges the expectations and beliefs of the patients since the disease often occurs in younger years when the individual usually expects to be in perfect health and wellbeing during those years. The disease occurrence distorts the person's confidence in his body and health (8).

Studies indicate that the patients with MS suffer from multiple psychological problems (9) so that such patients have low control over their emotions. The control of emotions is to learn how to recognize, express and control them in various situations (10) which affects different aspects of the individual life, interpersonal interactions, mental health, and the physical health (11).

The cognitive-behavioral therapy is among the interventions that have drawn attention of some researchers in recent years and its effectiveness has been confirmed in the treatment of some chronic medical conditions $(12,13)$. The cognitive-behavioral therapy is a structured and short-term approach, which has been founded based on clear concepts of the levels of cognition, including the schema (or core beliefs), assumptions (or mediating beliefs), automatic thoughts or imaginations, the recognition of constant and permanent mental representations, and their impact on the process of information. The cognitivebehavioral therapy emphasizes the importance of identifying the impact of patient's experiences on his beliefs system. The beliefs and schemas are shaped by the experiences and confrontation of the individual with events, people, and the situations. This approach emphasizes the role of critical events. The critical events compatible with the content of existing ideas and beliefs can activate them. These beliefs, in turn, can make the patients process information in a particular way (14).

Recent studies on the efficacy of cognitivebehavioral therapy have provided satisfactory results and rational reasons to use this therapeutic approach in clinical works, especially in the case of the psychological problems of MS patients. Accordingly, the studies conducted have discussed the effectiveness of cognitive-behavioral therapy as an appropriate intervention in improving the quality of life (15), reducing the mental fatigue $(8,13,16)$, improving the life expectancy (12), reducing anxiety and depression (17), reducing depression (18), and decreasing the physical complaints (19) of MS patients. 
Many MS patients do not have adequate knowledge and skills to manage their emotions properly. Hence, the psychological interventions such as cognitive-behavioral therapy seem to be necessary to improve the emotional control of MS patients. On the other hand, no direct study has been performed on the subject in our country (Iran) so far and a deep gap is seen in the available empirical concepts. Thus, we conducted this study was to determine the effectiveness of cognitive-behavioral therapy on emotional control of MS patients in Isfahan.

\section{Materials and Methods}

The present study was an experimental one with pre-test-post-test and the control group. The study statistical population included all members of the MS Society of Isfahan in 2016-2017. The sample consists of 30 people who were selected from the statistical population. A randomized sampling method was used to select the subjects from all members of the MS Society of Isfahan, which were randomly (even and odd method) in two experimental and control groups (15 in each group). Thus, the individuals were assigned codes with even and odd numbers. Subsequently, based on the codes (odd or even), they were divided into two groups (even codes for the control group and odd codes for the experimental group). Both groups answered to the emotional control questionnaire at the beginning and one month after the end of the research (end of the 8th session. Based on the previous studies $(17,18)$, an eight-session course (two onehour sessions per week for four weeks) of cognitive-behavioral therapy was held by researchers for the experimental group in one of the clinics affiliated with Isfahan University of Medical Sciences. In the control group, no training course was conducted. In addition, the cognitive-behavioral therapy was performed at different hours to prevent the transfer of educational concepts from the experimental group to the control group. Also, it was emphasized on the nondisclosure of the educational materials raised during the sessions by the experimental group to the control group.

After selecting the final study groups, the subjects of the two groups were asked to attend a briefing. In this meeting, it was tried to encourage the motivation and obtain the consent of the participants in the research by explaining the research objectives. To comply with the ethical principles, the consent form for collaboration in the research was completed by the participants. In addition, the researcher assured the participants that all the materials presented at the training sessions and the results of the questionnaires would be confidential. Meanwhile, anonymous questionnaires were used to respect the participants' rights.

The inclusion criteria included a definitive diagnosis of MS according to the specialists' opinions by physical and laboratory examinations, membership in the MS Society of Isfahan (regardless of any gender restrictions), having an from 20 to 40, having at least a diploma, receiving cognitivebehavioral therapy before participating in the research, inability to move due to severe motor problems as a result of the disease progression, agreeing to participate in research and signing a written consent. The exclusion criteria were the lack of cooperation and absence in two consecutive sessions and failure to answer the questions of the questionnaire.

The tool used in this study was an emotional control questionnaire. The emotional control questionnaire has been developed by Williams et al. in 1997 and has 42 questions and 4 subscales, including anger, depressed mood, anxiety, and positive affection. Each question is scored according to a 7-degree Likert scale (I fully agree to I 
completely disagree) (20). Williams et al. estimated the Cronbach's alpha coefficient for the whole questionnaire as 0.49 and its subscales in a range from 0.72 to 0.91 . They also reported the content validity of the questionnaire as appropriate (20). Faghih reported the internal consistency of the emotional control questionnaire to be 0.75 using the Cronbach's alpha method (21).

The cognitive-behavioral therapy was performed in a group as follows based on the White (14) therapeutic guideline for eight sessions (two one-hour sessions per week for four weeks):

(Meanwhile updating and reviewing the mood, establishing relationships with the past sessions, setting agenda, homework review, discussing on the items included in the agenda, assigning new assignments, preparing a periodic summary and preparing the final summary and feedback from the second session will take place during all the sessions).

In this research, the significant level was considered to be 0.05 . The data collected were analyzed using the descriptive statistics methods, including central tendencies (mean) and dispersion indices (standard deviation), and inferential statistics, including the univariate covariance analysis in the SPSS Ver. 20 software.

Table 1. Cognitive-behavioral therapy protocol

\begin{tabular}{|c|c|}
\hline Sessions & Content \\
\hline $\begin{array}{c}\text { Session } \\
1\end{array}$ & $\begin{array}{l}\text { Implementing the pre-test, introducing the members of the group and familiarizing with them, } \\
\text { establishing relationship, setting up a meeting agenda, checking and rating the mood objectively, } \\
\text { brief overview of the current problem, identifying problems and setting goals, presenting the logic } \\
\text { of treatment and teaching the cognitive-behavioral model, extracting the patients' expectations } \\
\text { from treatment, training and familiarizing the patients with MS disease, extracting the final } \\
\text { summary and receiving feedback, and providing homework }\end{array}$ \\
\hline $\begin{array}{l}\text { Session } \\
\quad 2\end{array}$ & $\begin{array}{l}\text { Updating and reviewing the mood, establishing a relationship with the past sessions, setting } \\
\text { agenda, homework review, discussion of items on the agenda, assigning new assignments, } \\
\text { preparing a periodic summary, preparing the final summary, getting feedback, and providing } \\
\text { assignments }\end{array}$ \\
\hline $\begin{array}{l}\text { Session } \\
\quad 3\end{array}$ & $\begin{array}{l}\text { Introducing, explaining and familiarizing the patients with the automatic thoughts and teaching to } \\
\text { identify automatic thoughts, evaluating the automatic thoughts during the session relative to the } \\
\text { MS illness, identifying problematic situations in case of inability to identify automatic thoughts, } \\
\text { teaching the mental relaxation, and providing a homework }\end{array}$ \\
\hline $\begin{array}{l}\text { Session } \\
4\end{array}$ & $\begin{array}{l}\text { Timing training and reviewing activities by using the activity table, identifying emotions, } \\
\text { differentiating between automatic thoughts and excitement and assigning homework }\end{array}$ \\
\hline $\begin{array}{l}\text { Session } \\
5\end{array}$ & $\begin{array}{l}\text { Understanding and identifying the common cognitive errors in the MS illness, assessment of } \\
\text { automatic thoughts and training the responding to automatic thoughts by using the inefficient } \\
\text { thoughts recoding sheet and behavioral tests, and providing assignments }\end{array}$ \\
\hline $\begin{array}{l}\text { Session } \\
\quad 6\end{array}$ & $\begin{array}{l}\text { Identification and correction of intermediate beliefs using the Socratic questioning technique, } \\
\text { assessing the advantages and disadvantages of a belief and the behavioral test, cognitive } \\
\text { conceptualization and proving the assignment }\end{array}$ \\
\hline $\begin{array}{l}\text { Session } \\
7\end{array}$ & $\begin{array}{l}\text { Training on fundamental beliefs and reviewing their functions and identifying them, correcting } \\
\text { fundamental beliefs using the fundamental belief worksheet and the technique of reviewing the } \\
\text { agreeing and opposing evidence and the downward arrow technique, providing the assignment }\end{array}$ \\
\hline $\begin{array}{l}\text { Session } \\
8\end{array}$ & $\begin{array}{l}\text { Problem-solving training, an overview of sessions, completion of treatment, relapse prevention, } \\
\text { and performing the post-test }\end{array}$ \\
\hline
\end{tabular}




\section{Results}

In this study, 16 women $(60 \%)$ and 14 men (40\%) diagnosed with MS participated, all of whom were married. The mean age (standard deviation) of the subjects in the experimental group was equal to $30.23 \pm 7.06$, while it was $29.34 \pm 7.15$ in the control group. In table 2, the descriptive statistics (mean and standard deviation) of the emotional control variable and its components in the two experimental and control groups are included in the pre-test and post-test conditions.
The Kolmogorov-Smirnov test (to assess the normal distribution of scores), the Levin test (for homogeneity analysis of variances) and the Box test (to examine the covariance matrix homogeneity) were used to examine the pre-assumptions of the univariate covariance analysis. These pre-assumptions were approved with the values $(P>0.05)$. Therefore, the univariate covariance analysis can be used. The results of the univariate covariance analysis are presented in Table 3.

Table 2. Descriptive statistics of the variable of emotional control and its components in the groups during the evaluation stages

\begin{tabular}{|c|c|c|c|}
\hline \multirow{2}{*}{ Variable } & \multirow{2}{*}{ Group } & Pretest & Posttest \\
\cline { 2 - 4 } & & $\mathrm{M} \pm \mathrm{SD}$ & $\mathrm{M} \pm \mathrm{SD}$ \\
\hline \multirow{2}{*}{ Anger } & Experimental & $32.00 \pm 3.85$ & $15.53 \pm 3.96$ \\
\cline { 2 - 4 } & Control & $31.40 \pm 3.43$ & $31.86 \pm 3.37$ \\
\hline \multirow{2}{*}{ Depressed mood } & Experimental & $39.53 \pm 6.18$ & $17.00 \pm 4.39$ \\
\cline { 2 - 4 } & Control & $39.13 \pm 6.09$ & $38.33 \pm 4.99$ \\
\hline \multirow{2}{*}{ Anxiety } & Experimental & $54.13 \pm 3.56$ & $27.60 \pm 4.80$ \\
\cline { 2 - 4 } & Control & $52.53 \pm 8.41$ & $51.86 \pm 8.66$ \\
\hline \multirow{2}{*}{ Positive emotions } & Experimental & $23.33 \pm 5.23$ & $50.86 \pm 5.42$ \\
\cline { 2 - 4 } & Control & $20.00 \pm 7.41$ & $20.46 \pm 7.27$ \\
\hline \multirow{2}{*}{ Total score } & Experimental & $71.66 \pm 14.13$ & $31.33 \pm 10.39$ \\
\cline { 2 - 4 } & Control & $67.06 \pm 19.11$ & $62.93 \pm 19.47$ \\
\hline
\end{tabular}

Table 3. The univariate covariance analysis results

\begin{tabular}{|c|c|c|c|c|c|c|c|}
\hline Variable & $\begin{array}{c}\text { Sum of } \\
\text { squares }\end{array}$ & $\begin{array}{c}\text { Degree of } \\
\text { freedom }\end{array}$ & $\begin{array}{c}\text { Mean of } \\
\text { squares }\end{array}$ & $\mathrm{F}$ & $\begin{array}{c}\text { Significan } \\
\text { ce level }\end{array}$ & $\begin{array}{c}\text { Eta- } \\
\text { square }\end{array}$ & $\begin{array}{c}\text { Statistical } \\
\text { power }\end{array}$ \\
\hline Anger & 709.560 & 1 & 709.560 & 103.97 & 0.001 & 0.839 & 1 \\
\hline $\begin{array}{c}\text { Depressed } \\
\text { mood }\end{array}$ & 1260.302 & 1 & 1260.302 & 120.08 & 0.001 & 0.857 & 1 \\
\hline Anxiety & 2377.510 & 1 & 2377.510 & 72.01 & 0.001 & 0.783 & 1 \\
\hline $\begin{array}{c}\text { Positive } \\
\text { emotions }\end{array}$ & 2682.671 & 1 & 2682.671 & 59.98 & 0.001 & 0.750 & 1 \\
\hline Total score & 35.806 & 1 & 35.806 & 0.125 & 0.001 & 0.415 & 1 \\
\hline
\end{tabular}


The cognitive-behavioral therapy has been effective on the components of anger $(P=0.001)$, depressed mood $(P=0.001)$, anxiety $\quad(P=0.001)$, positive emotions $(P=0.001)$, and the total score of emotional control $(P=0.001)$ in patients with MS. The test power obtained equal to 1 represents the appropriate sample size for such a conclusion (Table 3).

\section{Discussion}

The results of this study suggested that the cognitive-behavioral therapy training and its components are effective on the emotional control. Based on the results of this study, the cognitive-behavioral therapy is effective on the anger component of MS patients in Isfahan. This finding is consistent with the studies by Del Vecchio and O'Leary (22) and Qamari Kiwi et al. (23) suggesting the effectiveness of cognitive-behavioral therapy on anger. In the cognitive-behavioral therapy, changing the ineffective thinking content is the most effective way to change and modify the emotions and anxiety behaviors caused by anger in the patients with MS (22). Therefore, during the cognitive-behavioral therapy, the patients with MS understand the impact of the cognition on their emotions and behaviors and learn to identify the negative automatic thoughts in the anger-causing situations and their common cognitive errors and to replace them with more efficient thoughts. Continuing the process, the psychological relaxation training can lead the patients to experience physiological effects contrary to the excitement of anger. Finally, using the downward arrow method, they identify the negative underlying beliefs that initiate the anger. They respond to the MS disease by a new approach (such as dealing differently with the problem and solving the problem without resorting to aggressive strategies) through their empirical evaluation, analysis of negative beliefs, writing of their opposite beliefs and the positive interpretation of their angry-causing thoughts. This leads to anger reduction in patients with MS (23).

The cognitive-behavioral therapy appears to be effective on the depressed mood of MS patients according to the results of this study. This finding is consistent with the studies by Mokhtari et al. (18) and Zamani et al. (24) implying the effectiveness of cognitivebehavioral therapy on the depression of patients with MS. The cognitive-behavioral therapy is mainly associated with depression therapy. The ideas prominent in this area and the interventions based on them have always been seeking to develop and promote theoretical and practical models in describing the formation of inefficient thoughts and the methods of controlling them. The predications of MS patient about the events are completely intrinsic, general, and stable and based on negative cognitive styles so that these patients tend to negatively interpret everyday events and use cognitive errors, including arbitrary inference and extreme generalization. This occurs since they are drawn toward learned helplessness and focusing on the negative aspects of events due to their frequent confrontation with unpredictable and uncontrollable events. Therefore, due to the use of cognitive and behavioral techniques such as reviewing performance, identifying cognitive errors, identifying and modifying negative automatic thoughts and beliefs and intermediate and fundamental beliefs, the positive effect of cognitive-behavioral therapy on the depression of patients with MS can justify the decrease in the depressed mood scores of MS patients (18, 24).

Based on the results of this study, the cognitive-behavioral therapy is effective on the anxiety of MS patients in Isfahan. This finding is consistent with the studies of Zamani et al (25) and Sarafraznasb and Moin (17). These studies have also reported the 
effectiveness of cognitive-behavioral therapy on the reduction of anxiety in patients with MS. This finding can be explained by considering the role of cognitive factors (automatic thoughts, intermediate beliefs, fundamental beliefs, and impaired processing processes) in the pathology of MS. Thus, in the cognitive-behavioral therapy, it is tried to identify the automatic inefficient thoughts inducing the anxiety symptoms. The patient then becomes aware of the role of these thoughts and replaces them with more efficient thoughts. In addition, given that the MS patients show a high level of vulnerability to anxiety and are highly prone to misinterpret their physiological symptoms, they are informed during the treatment on their catastrophic and inaccurate thoughts regarding their health status and the course of the treatment of the disease, which causes a kind of negative and selective bias towards the health and the progress of recovery in them. Therefore, one of the effective behavioral techniques helping to explain the efficacy of the treatment is to perform mental relaxation exercises with the emergence of physiological signs of anxiety, which will decrease the anxiety by reducing the symptoms of tension (25).

According to the current study results, the cognitive-behavioral therapy is effective on the positive emotions of MS patients in Isfahan. This finding is consistent with the results of Patrizia et al. (26) studies, indicating the effectiveness of cognitive therapy based on the mindfulness in reducing negative emotion and the study by Hajir et al. (27), implying the effectiveness of cognitivebehavioral therapy in improving the emotional states of patients with MS. Due to incorrect beliefs that the negative affection in patients with MS is caused only by the illness, they cannot contribute to empowering their positive emotions. This strengthens the patients' misconceptions about emotional regulation and the same wrong cognitions leads to a greater avoidance of confrontation with positive emotions and strengthens the further tendency to control the positive emotions internally. Hence, the patients are captured in a defective cycle that strengthens the control of emotions inefficiently. However, the cognitive-behavioral therapy attempts to break down this defective cycle by using cognitive and behavioral methods. Therefore, it challenges the ill-fated knowledge of patients so that they would enter an efficient cycle. Thus, the increasing ability to review and re-adjust the intensity and direction of a positive emotion in themselves and others will affect the incorrect cognitions of MS patients and, in turn, modifying the false cognitions will lead to an increase in the positive emotions in them (26, 27).

\section{Conclusion}

This research, like any research, has encountered some restrictions as well. In this research, the intervention was performed only on patients with MS and it cannot be considered as interfering with other samples. Therefore, the generalization of the results to other people may be problematic. It is suggested to conduct a research with a similar topic to examine the impact of the interventions used in this study on other chronic medical conditions to compare the results with the findings of this study. This would accurately determine the comprehensibility of the results. In addition, failure to follow-up is another limitation of this research. It is suggested to do follow-up studies in long periods (at least one year). 


\section{Acknowledgements}

The present study is the result of a master's degree dissertation of the Islamic Azad University, Najafabad Branch, with the approved code of 15020701952003 . Hereby, the researchers would appreciate all the participants in this research. 


\section{References}

1. Tabrizi N, Etemadifar M, Sharif A, Mirmahdi R. Multiple sclerosis (MS). Volume 3. 7th ed. Tehran: Ghaed. 2012: 53- 62. (Persian).

2. Pourafkary N. Comprehensive dictionary of psychology-psychiatry: English-Persian. Vol. 2. 6th ed. Tehran: Farhang Moaser. 2007: p.962. (Persian).

3. Taghizadeh M, Asemi M. Assess the nutritional status of patients with MS. 3Th International Congress of MS. Iran. 2006; 152-153. (Persian).

4. Currie R. Spasticity: a common symptom of multiple sclerosis. J nurs stand. 2001; 15(33): 4758.

5. Kenner M, Menon U, Elliott DG. Multiple sclerosis as a painful disease. Int Rev Neurobiol. 2007; 79: 303-321.

6. Pugliatti M, Rosati G, Carton H, Riise T, Drulovic J, Vecsei L, Milano I. The epidemiology of multiple sclerosis in Europe. Review Article, Eur J Neurol. 2006; 13, 700-22.

7. Merkelbach S, Sittinger H, Koenig J. Is there a differential impact of Fatigue and physical disability on quality of life in Multiple Sclerosis? J Nerv Ment Dis. 2002; 190(6):13-22.

8. Soleimani S, Tajoddini E. Effectiveness of Cognitive Behavioral Therapy Based on Fatigue on Dimensions of Mental Fatigue in Patients with Multiple Sclerosis: a case study, Journal of Clinical Psychology. 2016; 2(3):13-22. (Persian).

9. Chwastiak AL, Gibbons EL, Ehde MD, Sullivan M, Bowen DJ, Bombardier HC. et al. (2005). Fatigue and psychiatric illness in a large community sample of persons with multiple sclerosis. J Psychosom Res; 59, 291-298.

10. Amstadter A. (2008). Emotion regulation and anxiety disorders. Anxiety Disorders; 22, 211222.

11. Dunham GD. (2008). Emotional Skill Falnes and Marital Satisfaction Unpublished Doctorral Disseration. University of okran.

12. Omrani S, Mirzaeian B, Aghabagheri H, Hassanzadeh R, Abedini M. Effectuality of Cognitive-Behavioral Therapy on the Life
Expectancy of Patients with Multiple Sclerosis, Mazand Univ Med Sci. 2012; 22(93): 58-65 (Persian).

13. Van Kessel k, Moss-Morris R, Willoughby E, Chalder T, Johnson MH, Robinson E. A randomized controlled trial of cognitive behavior therapy for multiple sclerosis fatigue. Psychosom Med. 2008; 70(2): 205-13.

14. White CA. Cognitive Behaviour therapy for choronic medical problems: A guide to assessment and treatment in practice. John Wily \& Sons Ltd, Baffins Lane, Chichester. 2001.

15. Asghari M, Hashemi Nasab B, Faraji F. Effect of Cognitive - Behavioral Stress Management quality of life and depression in female patients with MS Arak, Journal of Clinical Psychology Studies. 2011; 5(2): 1-24 (Persian).

16. Moss-Morris R, Dennison L, Landau S, Yardley L, Silber E, Chalder T. A randomized controlled trial of cognitive behavioral therapy (CBT) for adjusting to multiple sclerosis. J Cons clin psychol. 2013; 81(2): 251-62.

17. SarafrazNasab M, Moen Z. The effectiveness of cognitive-behavioral group therapy on reducing symptoms of anxiety, depression and create hope for MS patients, Third National Conference on Psychology and Behavioral Sciences; Tehran: Iran. 2015: 1-23. (Persian).

18. Mokhtari S, Neshat Doost HT, Molavi H. The Effect of Cognitive-Behavior Group Therapy on Depression and Dogmatization of Patients with Multiple Sclerosis (M.S.). Journal of Psychology. 2008; 12, 242-251. (Persian).

19. Mohr DC, Hart SL, Goldberg A. Effects of treatment for depression on fatigue in multiple sclerosis. Psychosomatic Medicine. 2003; 65, 542-547

20. Williams KE, Chambless DL, Ahrens AH. Are emotions frightening? An extension of the fear of fear concept. Behaviour Research and Therapy. 1997; 35, 239-248.

21. Fagih S. Couples effectiveness of Emotionally Focused distress tolerance, emotional adjustment and emotional control in infertile couples in Isfahan. [M. A. Dissertation]. Khorasgan Islamic Azad University. 2016. (Persian). 
22. Del Vecchio T, O'Leary KD. Effectiveness of anger treatments for specific anger problems: A meta-analytic review. Clinical Psychology

Review. 2004; 24,15-34

23. Qamari Kiwi H, Sheikh Eslami A, Adel Z. Cognitive - behavioral on anger and psychological well-being in aggressive female. Journal of Research Consulting. 2015; 14(55): 56-72. (Persian).

24. Zamani N, Barati F, Jahangir AH, Zamani S. Effectiveness of Cognitive Behavioral Therapy on Mental Health in Patients with Multiple Sclerosis. Health Research Journal. 2016; 1(4): 215-223. (Persian).

25. Zamani N, Rahmati A, Fazilat-Pour M. The Effect of Cognitive - Behavioral Stress Management Training on Anxiety, Depression and Cognitive Disorder of Individuals with Multiple Sclerosis. Journal of Clinical Psychology. 2014; 5(4): 43-54. (Persian).

26. Patrizia C, Nadav A, Llona B. TeachingMindfulness Based Cagnitive Therapy (MBCT) to students: The effect of MBCT on The Levels of mindfulness and Subjective Well-being. J couns Psychol Q. 2008; 4, 323-336.

27. Hazhir F, Ahadi H, Pourshahbaz A, Rezaei M. The application of cognitive behavioral therapy on Leventhals' model for improving quality of life in multiple-sclerosis patients. Journal of Kermanshah University of Medical Sciences. 2012; 16(2):100-108. (Persian). 


\section{اثربخشى درمان شناختى - رفتارى بر كنترل عواطف بيماران ام اس شهر اصفهان \\ مائده سادات علوى'، شيدا جبل عاملى '* \\ 1. كروه روانشناسى، واحد نجف آباد، دانشگاه آزاد اسلامى، نجف آباد، ايران}

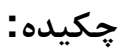

زمينه و هدف: درمان شناختى - رفتارى از جمله مداخلاتى است كه در سال هاى اخير در درمان بيمارى هاى مزمن يزشكى همجون ام اس به كار گرفته شده است؛ از اين رو يزوهش حاضر با هدف تعيين اثربخشى درمان شناختى - رفتارى بر كنترل عواطف بيماران ام دمان اس شهر اصفهان انجام شد.

روش بررسى: يزوهش حاضر از نوع نيمه تجربى مىباشد كه با استفاده از طرح بيش آزمون- يسآزمون با كروه كنترل انجام گرفت.

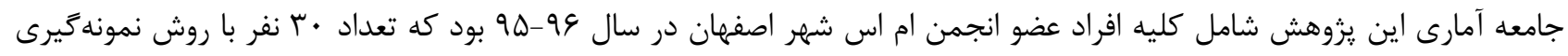
در دسترس انتخاب و به صورت تصادفى در دو گروه آزمايش و كنترل (ها نفر براى هر كروه) جايكزين شدند. هر دو تروه يرسشنامه

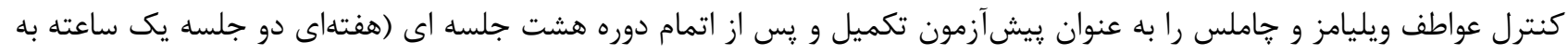

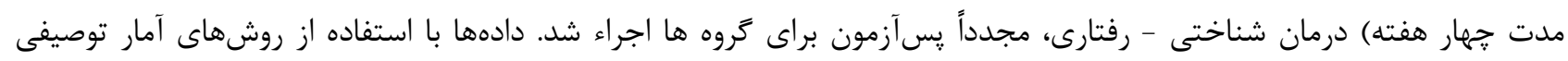

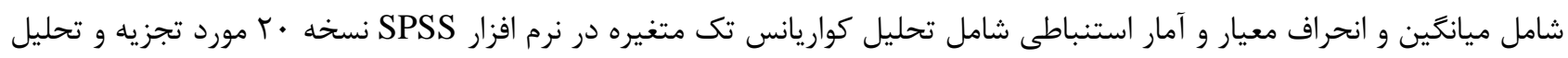
قرار ترفتند.

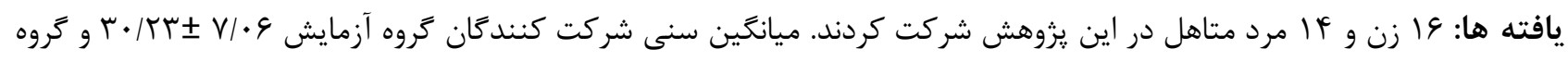
كنترل ه/l/

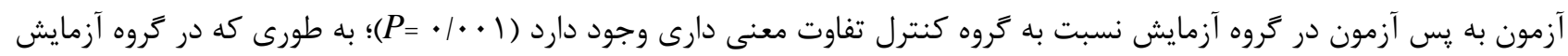
ميانكَين نمره كلى كنترل عواطف در مرحله يِيش آزمون

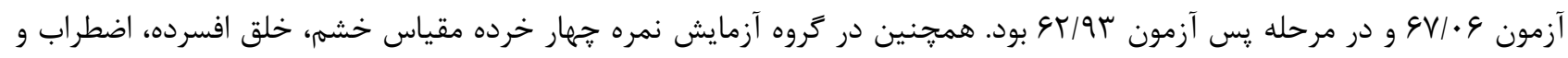

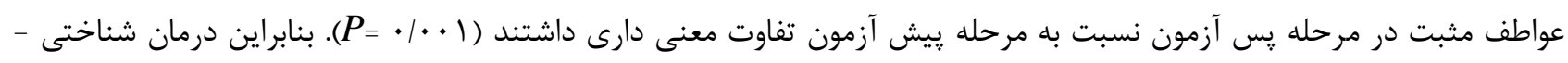

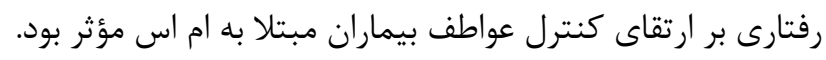

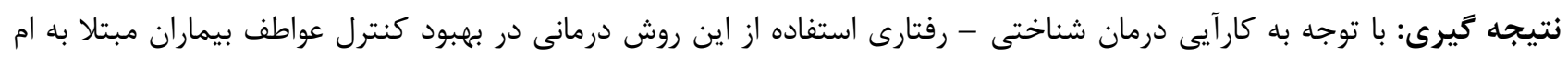
اس توصيه مى شود. كلمات كليدى: درمان شناختى - رفتارى، كنترل عواطف، ام اس تود

نويسنده مسئول: شيدا جبل عاملى

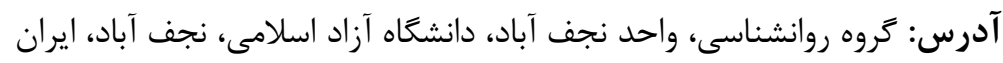
ايميل: sh.jabalameli@yahoo.com 